\title{
Bulgar Yazar İvan Lesiçkof'un Gözünden Balkan Harbinde Kırcaali Müfrezesi Ve Mehmed Yaver Paşa'nın Esareti ${ }^{1}$ Sinan Koçak ${ }^{2}$ \\ Hacı Bayram Veli University, Graduate Student, Department of History, Ankara, Turkey \\ Received- Accepted: 12.04.2019-19.05.2019 \\ Research Article
}

$\ddot{O} \mathbf{z}$

Tuğgeneral Mehmed Yaver Paşa, Balkan Harbinde Osmanlı Devletinin oluşturduğu Doğu ordusuna bağh Krrcaali Müfrezesinin komutanıdrr. Yaver Paşa elindeki imkanların kısitlı olması ve verdiği hatalı kararlar sonucunda Bulgarlara esir düşmüştür. Mağlup bir komutan olan Yaver Paşa hakkında elimizdeki bilgiler oldukça kssttlıdr. Bu yüzden İvan Lesiçkof un "Balkan Muharebatı Hatıratından" adlı eserinin Yaver Paşa ve Kircaali Müfrezesi hakkında verdiği bilgiler oldukça önemlidir. Ayrıca bu eser Balkan Harbinin gerçekleștiği tarihe yakın bir zamanda neşr edildiği için birinci el kaynak niteliğindedir. Ayrıca yazar İvan Lesiçkof un bizzat Balkan Harbine katılması ve gördüklerini kaleme alması bu eserin değerini artırmaktadır. Bununla birlikte Balkan Harbi hakkında komşumuz olan Bulgarların ne düşündüklerin anlamamı açısından da önemli bir eserdir.

Makalemiz İvan Lesiçkof un "Balkan Muharebatı Hatıratından" adlı eserinin birinci cüzz̈ olan "Yaver Paşa'nın Esareti” adlı kısmın transkripsiyon ve değerlendirilmesi sonucunda hazrlanmıştr. Lesiçkof un bu eseri Ankara da bulunan Milli Kütüphane'den tedarik edilmiştir. Ayrıca bu makalede telif ve tetkik eserlerden de yararlanılmıştır. Bu çalş̧mamızın amacı Lesiçkof un "Balkan Muharebatı Hatıratından" adlı eserine göre Mehmed Yaver Paşa'nın Birinci Balkan Harbinde Bulgarlarla yaptı̆̆ı mücadeleleri ve sonucunda esir düşmesi olayını birinci el kaynağa dayalı olarak incelemektir.

Anahtar Kelimeler: İvan Lesiçkof, Mehmed Yaver Paşa, Balkan Harbi, Kircaali Müfrezesi, Esaret

\section{From The Eyes Of Bulgarian Author Ivan Lesickof, Kardzhali Troops And The Captivity Of Mehmed Yaver Pasha In The Balkan Wars}

\begin{abstract}
Brigadier General Mehmed Yaver Pasha was the commander of the Kardzhali Troops of the Eastern Army formed by the Ottoman Empire in the Balkan war. Yaver Pasha was captivity to the Bulgarians as a result of his limited facilities and wrong decisions. The information we have about Yaver Pasha, a defeated commander, is very limited. For this reason, the information given by Ivan Lesiçkof about his Memoirs of the Balkan Battle is very important for Yaver Pasha and Kardzhali Troops. In addition, this work is the first hand source because it was published as the near date to the Balkan war. In addition, the author Ivan Lesichkof himself joined the Balkan war and wrote what he saw increase the value of this work. However, it is an important work to understand what Bulgarians think about the Balkan War.

This article was prepared as a result of the transcription and evaluation of the part of Ivan Lesickofs The Captivity of Yaver Pasha which is the first chapter of his, Memoirs of the Balkan Battle. This work of Lesickof was obtained from the National Library in Ankara. In addition, books and articles were also used in this article. The aim of this study was to investigate the struggle of Mehmed Yaver Pasha with Bulgarians in the First Balkan War and as a his captivity. This study is based on first-hand resources
\end{abstract}

Keywords: Ivan Lesickof, Mehmed Yaver Pasha, Balkan Wars, Kardzhali Troops, Captivity

\footnotetext{
${ }^{1}$ Bu makale Doç. Dr. Meşkure Yılmaz danışmanlığında hazırlamakta olduğum Hacı Bayram Veli Üniversitesi Lisansüstü Eğitim Enstitïsüne sunulacak olan "Bulgar Yazar İvan Lesiçkof un "Balkan Muharebatı Hatrratından” adlı eserine göre: Birinci Balkan Savaşı" başlklı yüksek lisans tezinden üretilmiş̧ir.

*This article is analyzed by two reviewers and it is screened for the resembalance rate by the editor. (Bu makale iki hakem tarafindan incelenmiş ve editör tarafindan benzerlik oranı taramasundan geçirilmiștir)

2 sinan.kocak9393@gmail.com, ORCID: 0000-0001-7481-0100.
} 
Bulgar Yazar İvan Lesiçkof'un Gözünden Balkan Harbinde Kırcaali Müfrezesi ve Mehmed Yaver Pașa’nın

Esareti/Sinan KOÇAK

\section{Giriş}

Balkan Harbi, Osmanlı Devleti’nin dağılma sürecinde yaşadığı önemli bir olaydır. Trablusgarp savaşının devam ettiği sırada patlak veren Balkan Harbi, Osmanlı Devletini zor duruma soktu. Balkan Harbinin başlaması sebebiyle Osmanlı Devleti ordularını Balkanlara yönlendirdi. Çünkü Balkanlar uzun bir süredir Osmanlı Devleti'nin hâkimiyeti altındaydı ve sosyo-kültürel bir bağ ile Osmanlı Devleti'ne bağlıydı. Bununla birlikte Balkan topraklarn kaybedilirse Anadolu topraklan da tehlikeye girebilirdi.

Balkan Harbi, sadece Osmanlı Devleti ile Balkan ittifakındaki devletleri ilgilendirmiyordu. Avrupalı büyük güçler de bu olayı yakından takip ediyorlardı. Çünkü Balkan topraklarında kendi çıkarları söz konusuydu. $\mathrm{Bu}$ açıdan bakıldığında, Balkan Harbi birçok ülkeyi ilgilendirdiği için çeşitli dillerde çok sayıda eser kaleme alınmıştır. Balkan Harbi gibi önemli bir olayı doğru bir şekilde yorumlamak istiyorsak sadece kendi kaynaklarımızı kullanmamız yeterli olmayabilir. Bu yüzden yabancı kaynaklan da inceleyip, bu kaynakları iyi bir şekilde tenkit etmemiz gerekir. Bu çalışmamızda Balkan Harbine bizzat şahit olmuş İvan Lesiçkof'un 'Balkan Muharebatı Hatıratından" adlı eseri incelenmiş ve sadeleștirilmesi yapılmıştır. Bu eserin birinci cüzü olan "Yaver Paşa’nın Esareti” adlı kısmı M.Nuri tarafindan Bulgarcadan Osmanlı Türkçesine çevrilmiştir.

İvan Lesiçkof, 1876-1958 tarihleri arasında yaşamış yayınevi sahibi, kırtasiyeci-kitapçı, çevirmen ve yazardır. Troyan'da doğmuş olan Lesiçkof, 20.yüzyılın başında Şumen'e yerleşmiştir. 1902'de Lesiçkof, Svetlina adlı bir kitapçı-kırtasiye açmıştır. Daha sonra bunlara yayınevi de eklemiştir. 1908'e kadar bu işi devam ettiren Lesiçkof, çeşitli alanlarda 150'den fazla eser basmıştır. Lesiçkof, 20.yüzyılın 20'li yıllarında Sofya'ya taşınmıştır. Svetlina isimli yayınevinde faaliyetlerine devam etmiştir. Lesiçkof kurduğu aile şirketinde farklı lisanlarda birçok eser ve nadir eserler basmıştır.(Doğruöz, 2016, s.302-303)

Lesiçkof'un “Balkan Muharebatı Hatıratından” adlı eseri 1913 yılında Filibe'de Balkan Matbaasında basılmıştır. Bu eser dört cüzden oluşmaktadır. Bu cüzler şunlardır:

I.Cüz Yaver Paşa'nın Esareti,

II.Cüz Kırkkilise’nin Sukütu,

III.Cüz Manastır ve Pirlepe Muharebatı,

IV.Cüz Selanik Nasil Düştü? .

İlk üç cüz M. Nuri, dördüncü cüz ise H. Sıdkı tarafindan Bulgarcadan Osmanlı Türkçesine çevrilmiştir. (Doğruöz, 2016, s.303-304) Bu çalışmanın temel kaynağı olan Lesiçkof'un "Balkan Muharebatı Hatıratından" adlı eserinin I.Cüzü olan "Yaver Paşa'nın Esareti” adlı kısımdır. Bu kısım Ankara da bulunan Milli Kütüphaneden tedarik edilmiştir.

Bu makale çalışması üç bölümden oluşmaktadır. Birinci bölümde, Birinci Balkan Harbinin sebepleri, gelişim ve sonuçları hakkında bilgiler verilmiştir. İkinci bölümde, Mehmed Yaver Paşa’nın komutanı olduğu Kırcaali Müfrezesi hakkında bilgiler verilmiştir. Üçüncü bölümde ise asıl konumuz olan İvan Lesiçkof'un 
"Balkan Muharebatı Hatıratından" adlı eserine göre Mehmed Yaver Paşa’nın Bulgarlar ile mücadelesine ve sonucunda esir düşmesi konusu üzerinde durulmuştur.

Mehmed Yaver Paşa hakkında elimizdeki bilgiler oldukça kısıtlıdır. Yapılan kaynak ve arşiv taramaları sonucunda Mehmed Yaver Paşa hakkında en detaylı bilginin İvan Lesiçkof'un bu eseri olduğu sonucuna varılmıştr. Bununla birlikte bu kitabın bir Bulgar yazar tarafindan yazılmış olması bu olaya farklı açıdan bakmamıza yardımcı olmuştur.

\section{Birinci Balkan Harbi}

İkinci Meşrutiyet'in 1908 Temmuzunda ilan edilmesiyle birlikte bir dizi olay gerçekleşti. Bu olaylar şunlardır: Avusturya'nın Bosna-Hersek'i ele geçirmesi, Bulgaristan'ın bağımsızlğııı kazanması, Yunanistan'ın Girit'i ele geçirme teşebbüsü, Arnavutların ve Arapların bağımsızlı isteklerinin gün geçtikçe artması ile İtalyanların Trablusgarp’a saldırması.(Armaoğlu, 1999, s.651)Yukarıda bahsedilen tüm olaylar Balkan Harbinin başlamasına zemin hazırladı. Özellikle İtalyanların Trablusgarp'a saldırmasını firsat bilen Balkan devletleri Osmanlı üzerine harekete geçtiler. Trablusgarp Savaşının yanı sıra bahsedilmemiş diğer başka önemli sebeplerde vardır. Bunlardan birisi şüphesiz Fransız İhtilalidir. Fransız İhtilali’nin yaydı̆̆ milliyetçilik ve bağımsızlık gibi fikir akımları Balkan Devletlerini büyük ölçüde etkiledi ve Osmanlı Devletine karşı bağımsızlık hareketlerine girişmelerine sebep oldu.

Balkan Harbi öncesi Balkan Devletlerinin amaçlarına bakacak olursak: Sirplar, Makedonya üzerinden Ege denizine çıkmayı amaçlıyordu. Bulgaristan'a bakacak olursak: Bulgar Kralı Ferdinand, 5 Ekim 1908'de bağımsızlığın ilan edildiği gün tacı Sofya'da değil, Orta Çağ Bulgar Krallı̆ının merkezi olan Tırnova'da giydi. Bu da eski Bulgar krallığna özlem duyulduğu anlamına gelmekteydi. Bulgarlar için ilk hedef Makedonya oldu. Yunanistan ise: Megalo İdea'nın peşindeydi. Yunan Başbakanı Venizelos 1911 Martında yaptığı konuşmada açik bir şekilde "Helenizm" ve "Megalo İdea"dan bahsetmekteydi. Yunanistan amacı Makedonya'nın Ege Kıyları, bütün Ege adaları ve Girit'ti. Görüldüğü üzere, Yunanlar, Bulgarlar ve Sirplar Osmanlı toprağı olan Makedonya'ya göz diktiler. Bu toprak üç balkan devleti arasında sürekli bir rekabet ortamının oluşmasına sebep oldu. Çünkü bu üç Balkan Devletinin her biri Makedonya’yı bir bütün olarak ele geçirmek istiyordu.(Armaoğlu, 1999, s.653-654)

Balkan Devletleri, Rusya'nın yoğun çabaları sonucunda kendi aralarında ittifak antlaşmaları yaptılar. Bulgar-Strp İttifakı: Balkan ittifakı için ilk olarak Bulgar Hükümeti harekete geçti ve Surp hükümetiyle görüşmeye başladı. Yapılan görüsşmeler sonucunda 1912 Mart ayında ittifak antlaşması imzalandı. Bulgar-Yunan İttifakı: İttifak anlaşması Sofya'da 29 Mayıs 1912'de imzalandı. Sırp-Yunan devletleri arasında bir ittifak anlaşması yapılmadı. (Bayur, 1943, s.197-226)Karadağ-Yunanistan İttifakı: Yeni Pazar Sancağı ve İşkodra karşllğında Karadağ 1912 Mayısında Yunan hükümetine yardım edeceğini vaat etti. Karadağ-Bulgaristan İttifakı: 26 Ağustos 1912'de Karadağ ile Bulgaristan arasında sözlü bir ittifak antlaşması yapıldı. Karadağ-Sırbistan İttifakı: 6 Ekim 1912 tarihinde imzalandı. Bu ittifak anlaşmasılyla birlikte Surbistan, Bulgaristan, Yunanistan ve Karadağ’dan 
Bulgar Yazar İvan Lesiçkof'un Gözünden Balkan Harbinde Kırcaali Müfrezesi ve Mehmed Yaver Pașa'nın

Esareti/Sinan KOÇAK

oluşan Balkan İttifakı tamamlandı. (Bodur, 2005, s.95-96)

Avrupalı güçler Balkanlarda yaşanan gelişmeleri yakından takip ediyorlardı. Özellikle Rusya ve Avusturya bu süreci en yakından takip eden devletlerdi. İngiltere Dış İşleri Bakanı Edward Grey, Rusya ile Avusturya'nın bu konu üzerinde uzlaşma içerisinde bulunması gerekliliğini vurguluyordu. Rusya ve Avusturya, Osmanlı Devleti'ne Balkanlarda yerel reformlar yapması konusunda birlikte baskı uyguladılar. (Akın, 2017, s.215)Çünkü Balkanlarda aktif olan büyük güçler Rusya ve Avusturya idi. Bu yüzden iki devlet birbiriyle çatısma ortamına girecek olursa diğer büyük güçlerde bundan etkilenecekti.

Rusya, Avusturya'nın olaylara müdahale etmesini ve ona karşı savaşa dâhil olmayı istemiyordu. Fakat Balkan birliğinin oluşması sırasında kazandığı bölgedeki itibarını da kaybetmek istemiyordu. Fransa ise, oluşan Balkan birliğinin Almanya'yı zor duruma düşüreceği için bu durumdan memnundu. Bu sebepten ötürü, Avusturya ve Almanya, Rusya’ya savaş açarsa Fransa, Rusya'nın yanında yer alacağı konusunda garanti verdi. İniltere ise, Balkanlardaki düzenin değişmesini istemiyordu ve yeni bir savaşa karşıydı. Görüldüğü üzere, Üçlü İttifak ve Üç İtilaf devletleri Balkanlar'da bir kez daha karşı karşıya geldiler. Aralarındaki güç dengeleri olağan bir savaşın çıkmasını şımdilik engelliyordu. Bu nedenle de, görünürde büyük devletler barışın korunması tarafindaydı. Fakat iş icraata geldiğinde hiçbiri sorunu çözmek için bir adım atmadı. (Uçarol, 2013, s.536)

30 Eylül 1912'de Büyük Devletlerin tutumlarından cesaret alan Balkan Devletleri seferberlik ilan ettiler. Bu durum üzerine Osmanlı Devleti de1 Ekim 1912'de seferberlik ilan etti ve bazı tedbirler almaya başladı. Balkan Devletlerinin yaptıkları faaliyetler Türk kamuoyunda savaş kararı alınması için harekete geçilmesine sebep oldu. Böyle bir atmosferde 7 Ekim 1912'de Karadă̆, Osmanlı Devleti'ne savaş ilan etti. Buna cevap olarak aynı gün Osmanlı Devleti de Karadağ’a savaş ilan etti. Böylece 8 Ekim 1912 tarihinde savaş fiilen başladı. 17 Ekim 1912'de Bulgaristan ile Sirbistan, 18 Ekim 1912'de Yunanistan Osmanlı Devleti'ne savaş ilan etti ve böylece Balkan devletleri amaçlarına ulaşmış oldu. (Uçarol, 2013, s.536-537)

Balkan Harbinin başlangıcında Osmanlı ordusunun durumu oldukça kötü bir vaziyetteydi. Bunun ilk sebebi, bölgedeki usta askerlerin terhis edilmesi ve takviye olarak gönderilen askerlerin tecrübesiz olmasıydı. Bununla birlikte yönetici subaylar mesleklerini bir kenara bırakıp politikaya dâhil olmuşlardı. Orduda ki diğer bir sorun eğitimdi. Askerler eğitim, öğretim ve disiplinden yoksun bir haldeydi. Ayrıca askerlerde emre itaat, sabır, dayanıklılık ve cesaret gibi temel unsurlar oldukça zayıftı. Ordudaki başka bir sorun ise nakliye idi. Genelkurmay Başkanı Hadi Paşa, Edirne Kalesine hiçbir şey gönderilemediğinden ve bürokraside yaşanan kargaşadan şikâyet etmişti. (Yalçın, Akbıyık vd., 2011, s.60-62)Görüldüğü üzere, Osmanlı ordusu personel, eğitim ve nakliye gibi temel konularda sorunlar yaşamaktaydı. Bu durum ordunun savaşa hazır olmadığının bir göstergesidir.

Osmanlı Devleti ordusunu Balkanlarda Doğu ve Batı ordusu olarak ikiye ayırmıştı. Sefer planına göre toplam asker sayısı 812.663 olarak belirlenmişti. Ancak, savaşın başlarında 21 Ekim 1912'de asker mevcudu 290.000 idi. Aynı tarihlerdeki Balkan Devletlerinin ordularının toplamı ise yaklaşık 482.000 idi. Osmanlı'nın 115.000 kişiden oluşan 'Doğu Ordusu”, Trakya'da Bulgarlar ile mücadele edecekti. 175.000 mevcutlu "Batı Ordusu” ise Makedonya ve Arnavutluk’ta Yunan, Sirp ve Karadağllarla mücadele edecekti. Bu bakımdan 
Balkan Harbi, Doğu ve Batı Cephesi olarak iki cephede gerçekleşti. (Uçarol, 2013, s.539-540)Osmanlı ordusunun seferberliğinin düzgün bir ş̧ekilde yürütïlemediği aşikârdır. Çünkü hedeflenen asker sayısının yaklaş̧k yarısına bile ulaşllamamıştır. Balkan Devletlerine baktığımızda asker sayısının Osmanlı ordusundan sayıca daha fazla olduğu görülmektedir. Bu durum Balkan Devletlerinin yaptkları savaşları kazanmalarnda etkili bir unsur haline gelecektir.

Bulgarlar, 21-23 Ekimde Edirne ile Kırklareli arasında yer alan Sütoğlu ve Pınarhisar muharebelerini kazandı. Daha sonra 28 Ekim- 2 Kasımda Lüleburgaz muharebesini de kazandılar. Böylece Türk ordusu dağldı ve geri çekilmeye başladı. Bunun üzerine Kurklareli düştü. Hatta düşman Çatalca önlerine kadar geldi. Düşman 15-19 Kasımda müthiş bir şekilde Çatalca hattını zorladılar. Fakat başarlı olamadılar. Surplar ise, 20 Ekimde Priştine'yi aldılar. İki gün sonra Türklerin Batı ordusunu, Kosova meydan muharebesinde bozguna uğrattılar. Surplar, Veliahd Aleksandr'ın kumandası altında güneye doğru ilerlerken, Yunanlar 22 Ekim'de Serfiçeyi aldıktan sonra kuzeye doğru ilerliyordu. 23 Ekimde Prens Aleksandr Yenipazarı ele geçirdikten sonra batıdan gelen Karadağ ve doğudan gelen Bulgar kuvvetleriyle birleşti. (Çalık, 2015, s.15-16)

Güneyden artan Yunan baskilarına dayanamayan Türklerin Batı Cephesi çöktï. Yunanlar, 25 Ekim'de Vistriça'yı geçti ve Karaferye'yi işgal etti. Böylece Vardar’a yaklaştılar. 26 Ekimde Surp-Bulgarlar İş̧ip’e ve aynı gün büyük bir Türk eyalet merkezi konumundaki Üsküp şehrine girdiler. Daha sonra Türklerin diğer bir eyalet merkezi Manastır ele geçirildi. Preveze'yi 6 Kasım'da ele geçiren Yunanlar, Prens Konstantin kumandasındaki büyük kuvvetlerini Selanik üzerine gönderdi. Selanik’i savunmakla görevli olan Tahsin Paşa, tek bir mermi atmadan muazzam kolordusunu silahlarıyla birlikte Yunanlılara teslim etti. 6 Kasım'da Sirp-Karadağllar, Yakova'yı ele geçirdi. 18 Kasım'da Leş ve Debre'yi zapt ettiler. 28 Kasım'da Adriyatik üzerinde yer alan Tirana'nın limanı Draç ve 29 Kasım'da ise Ohri işgal edildi. Tirana ve Akçahisar'ın zapt edilmesiyle birlikte, tüm Kuzey Arnavutluk bölgesi Sırp-Karadağıllar'n eline geçmişti. Kasım ayına gelindiğinde Türk orduları her tarafta mağlup edilmişti. Müttefikler, Çatalca ile Adriyatik arasında yer alan ülkeleri işgal etmişti. Sadece Edirne, Yanya ve İ̧̧kodra kaleleri dayanıyordu. Bulgarlar, Çatalca önünde durdurulabilmişti. (Çalık, 2015, s.16)

Balkan Devletlerinin orduları Osmanlı Devleti için gün geçtikçe daha tehlikeli bir hale geliyordu. Bu yüzden Sadrazam Kamil Paşa, savaşın durdurulması ve ön barış görüşmelerinin başlaması için harekete geçti. 25 Kasım 1912'de Çatalca'da Osmanlı ile Bulgar temsilciler arasında ilk görüş̧meler başladı. Türk tarafinın mütareke hakkındaki görüşlerini Bulgarlar kabul etti. Ancak Yunanllların önerileri kabul edilmedi. Bu yüzden Yunan delegeleri mütareke yapmaktan vazgeçip toplantıdan ayrıldılar. Bununla birlikte, 3 Aralik 1912'de Türk ve Bulgar temsilciler arasında Çatalca Mütarekesi imzalandı. (Uçarol, 2013, s.541-542)

Bu mütarekenin başlıca maddeleri özetle şu şekildedir:

Barış görüşmelerine başlanılabilmesi amacıyla Osmanlı Devleti ve diğer taraftaki Bulgar, Surp ve Karadağ ordularıyla mütareke yaptı. Çatalca mütarekesinin imzasından 20 gün sonra barış görüşmeleri Londra'da başlayacaktır. Taraflar arasında bir "tarafsız bölge" oluşturulacaktır. Eğer barnş yapılmazsa, taraflar 4 gün önceden 
Bulgar Yazar İvan Lesiçkof'un Gözünden Balkan Harbinde Kırcaali Müfrezesi ve Mehmed Yaver Pașa'nın

Esareti/Sinan KOÇAK

birbirlerine mütarekenin ne zaman son bulacağını bildireceklerdir. Osmanlı Devleti, Karadeniz deki ablukasını kaldıracak ve Bulgar askerlerinin limanlardan faydalanmasina engel olmayacaktır. Ayrica Bulgar askeri trenlerinin Edirne içinden geçmelerine de izin verilecektir. (Bayur, 1943, s.141)

13 Aralık 1912'de Londra'da barış görüşmeleri başladı. Bu görüşmelerin asıl amacı Osmanlı Devleti ile Balkanlı müttefikler arasındaki sınır ve toprak sorunlarına çözüm bulmaktı. Bu görüşmeler devam ederken 17 Aralıktan itibaren Londra'da Elçiler Konferansı da başladı. Bu konferansta görüşülen konulardan birisi Ege Denizi'ndeki adalar meselesidir. İngiltere ile Fransa, İmroz, Bozada, Limni ve Semendire gibi adalarn Yunanistan'a verilmesini istiyorlardı. Böylece Rusya'nın adalarda güç sahibi olmasını engelleyebileceklerini düşünüyorlardı. Rusya ise zaylf bir devlet olarak gördüğü Osmanlı'da kalmasını istiyordu. Elçiler Konferansında durum böyleyken 6 Ocak 1913'te asıl barnş konferansinda bir sonuca varlamadığ için konferans son buldu. $\mathrm{Bu}$ durum oluşmasında en önemli etken sııır meseleleriydi. Osmanlı hükümeti uzlaştıııı bir tavır takındıysa da Balkan Devletleri Edime'yi almakta ısrarcıydılar. Fakat Osmanlı Hükümeti de Edirne'den vazgeçmeyince barış görüşmeleri son buldu. (Armaoğlu, 1999, s.676-677)

Barış görüşmelerinin son bulması Avrupa'da bir panik havası yarattı. Büyük devletler savaşın yeniden başlamasından endişeliydiler. Bu yüzden Üçlü İttifak ve Üçlü Itillaf devletleri Osmanlı Devleti’ne 17 Ocak 1913 'te ortak bir nota gönderdi. Bu notada Edirne'den vazgeçilmesini ve Ege adalarının geleceğini büyük devletlere bırakılması gerektiğini de vurgulamışlardır. Osmanlı hükümeti, Büyük devletlerin notasına 30 Ocak 1913’te cevabını verdi. Cevabı özet olarak şu şekildeydi: Osmanlı hükümeti, Edirne'yi ve Ege adalarını vermeyi kabul etmiyordu. Ayrıca hükümet kapitülasyonlarnnda kaldırılmasını istiyordu. Osmanlı Devleti'nin ret cevabını vermesi üzerine, muharebeler 3 Şubatta yeniden başladı. Muharebelerin çoğu Osmanlı'nın aleyhinde bir gelişme gösteriyordu. Osmanlı ordusu bir yandan Çatalca'da savaşmaya devam ederken diğer yandan da Bulgarların peşine düşmüştü ayrıca Edirne'yi kurtarmak amacıyla da Şarköy’e asker çıkarmışlardı. Fakat başarılı olunamadı. Bu yüzden Osmanlı Hükümeti, özellikle İngiltere nezdinde teşebbüse geçerek 20 Şubattan itibaren barış arayışına girişti. Osmanlı Devleti artık Edirne'yi ve Ege adalarıı İngiltere, Fransa, Rusya ve Avusturya gibi büyük devletlerin aracllı̆̆na bırakmayı kabul ediyordu. Çünkü İstanbul konusu tekrar gündeme getirilmiş̧ti. Osmanlı Devleti, Edirne, Adalar ve İstanbul konusunda zor durumdayken diğer cephelerdeki durumuna bakacak olursak, 6 Martta Yanya şehri Yunanlllara, 26 Martta Edirne şehri Bulgarlara ve 23 Nisanda İskodra'da Karadağılara teslim oldu. (Armaoğlu, 1999, s.677-678)

Yukarıda belirttiğimiz gelişmelerin devam ettiği sralarda Büyük devletler bölgede barışın sağlanması ve savaşı sonlandırmak amacılla harekete geçtiler. Osmanlı Devleti ile Balkan Müttefik devletleri arasında görüşmeler yapıldı ve nihayetinde 30 Mayıs 1913’te Londra Barış Antlaşması imzalandı. Bu antlaşma yedi maddeden oluşmaktaydı. (Uçarol, 2013, s.550) Özetle antlaşmanın maddeleri şu şekildeydi:

Midye-Enez hattının batısındaki topraklar Müttefik devletlere bırakıldı. Osmanlı Sultanı ve Müttefik devletlerin hükümdarları Amavutluk sınılların çizecek ve bu ülke ile ilgili tüm sorunları çözme işi İngiltere, Fransa, Rusya ve Avusturya gibi büyük devletlere brakıldı. Osmanlı Sultanı, Girit üzerindeki bütün haklarmı 
Müttefik devletlere bıraktı. İki taraf Ege adaları üzerindeki karar verme haklarını Büyük devletlere devretmişlerdir. Savaş sonrası ortaya çıkan mali sorunları çözmek amacıyla Paris’te bir uluslararası bir komisyon oluşturulacaktır. Ayrıca savaş tutsakları ve diğer meseleler anlaşmalarla çözüme kavuşturulacaktır. (Bayur, 1943, s.313)

Londra Barış Antlaşması ile birlikte Birinci Balkan Harbi son buldu. Osmanlı Devleti uzun yıllardır hüküm sürdüğü Balkan topraklarını kaybetti. Savaş sonucunda Balkan Devletleri, Osmanlı mirası yüzünden kendi aralarında sorunlar yaşamaya başladılar. Özellikle Bulgaristan'ın güçlendiğini düşünen diğer Balkan Devletleri İkinci Balkan Harbinin çıkmasına sebep olacaklardır.

\section{Kurcaali Müfrezesi Ve Mehmed Yaver Paşa}

Balkan harbinde Osmanlı Devleti'nin ordusu Doğu ve Batı olmak üzere ikiye ayrılmıștı. Trakya'daki Doğu ordusunun başında Abdullah Paşa, Makedonya'daki Batı ordusunun başında ise Ali Rıza Paşa vardı. (Y1ldırım, 2014, s.118) Osmanlı Devleti'nin Doğu ordusu toplam dört nizamiye kolordusu (I., II., III. ve IV. kolordular), geçici üç mürettep kolordu (XV., XVI. ve XVII. kolordular), bir mürettep bağımsız süvari tümeni ve bir bağımsız süvari livasından oluşuyordu. Harp için görev teşkilatının hazırlanmasından sonra, Trakya'daki Osmanlı kuvvetleri üç ayrı komutanlığa ayrıldı. Bu komutanlıklar şunlardır: Doğu ordusu, Edirne Müstahkem Mevkii ve Kırcaali ${ }^{3}$ Müfrezesi. (Erickson, 2013, s.101) Bizim asıl konumuz Kırcaali Müfrezesidir. Görüldüğü üzere, Kırcaali Müfrezesi Trakya'daki Doğu ordusunun bir parçasıdır. Buradan itibaren Kırcaali Müfrezesinin Balkan harbindeki sefer kuruluşu, mevcudu, harekât ve seferberlik planları gibi konulara temas edilecektir.

Kırcaali Müfrezesine geçmeden önce şu hususa değinmemiz doğru olacaktır. Kaynaklar incelendiğinde birden fazla Yaver Paşa'nın mevcut olduğu ortaya çıkmaktadır. Bunlardan en çok karıştırılanı şüphesiz Ömer ${ }^{4}$ Yaver Paşa'dır. Ömer Yaver Paşa Balkan harbinde Doğu ordusuna bağlı oluşturulan Birinci Nizamiye kolordusuna komutanlık yapmıştır. Bizim için önemli olan Kırcaali Müfrezesi komutanının kim olduğudur. Diğer bir isim ise Ali Yaver Paşadır. Ali Yaver Paşa, Hikmet Bayur'un 'Türk İnkılabı Tarihi” adlı eserinde Kırcaali Müfrezesinin komutanı olarak geçmektedir. Biz bu çalışmamızda Genelkurmayın yayınlamış olduğu "Balkan Savaşı'na Katılan Komutanların Yaşam Öyküleri”' adlı çalışmasında geçtiği şekilde Kurcaali Müfrezesinin komutanı olarak Mehmed Yaver Paşa'yı kabul edeceğiz. Bu kaynağı kabul etmemizin sebebi askeri arşiv belgelerine dayalı olmasıdır.

Kırcaali Müfrezesinin komutanı Tuğgeneral Mehmed Yaver Paşa'dır. Bu müfrezenin kurmay başkanı

\footnotetext{
${ }^{3}$ Güneydoğu Bulgaristan'da bulunan Kırcaali bölgesi, Arda ırmağının kıyısında ve doğu Rodop dağlarında yer almaktadır. Hasköy ve Gümülcine'ye şose yolları vardır. (Acaroğlu, 1988, s.241-242)

${ }^{4}$ Çerkeş’te doğmuş olan Ömer Yaver Paşa'nın babasının adı Ahmet’tir. 1931 ylında öldüğü bilinmektedir. Balkan Savaşlarında 1 nci Kolordu Komutanlığı görevinde bulunmuştur. Ayrıca Kırklareli ve Çatalca muharebelerine katılmıştır. Ancak bu muharebelerde bir başarı gösterememiştir. 22 Eylül 1913 tarihinde emekliye ayrılmıștır. ( Genelkurmay, 2004, s.21-22)
} 
Bulgar Yazar İvan Lesiçkof'un Gözünden Balkan Harbinde Kırcaali Müfrezesi ve Mehmed Yaver Pașa'nın

Esareti/Sinan KOCCAK

ise Binbaşı Mehmet Hayri Bey'dir. Bunların yanı sıra Albay rütbesinde Rasim ${ }^{5}$, Yusuf ${ }^{6}$ ve Hüseyin Hüsnü ${ }^{7}$ Beyler bu müfrezede görev yapmıştır. Ayrıca Binbaşı Rıza Bey'de müfrezenin ileri gelen subaylarından birisidir.(Görgülü, 1993, s.23)

Kırcaali Müfrezesi'nin sefer kuruluşuna bakacak olursak: Müfreze karargahı, bir telsiz telgraf müfrezesi, bir istihkam, bir süvari ( Edirne Müstahkem Mevkiinden verilecek), bir sıhhiye bölüğü, Kurcaali Redif Tümeni ( 36 ncı Piyade alayı dahil ), Kurcaali Müstahfiz Tümeni, yalnız bir bataryadan oluşan adi ateşli dağ topçu taburu ve iki bataryalı seri ateşli dağ topçu taburundan oluşmaktaydı. (Genelkurmay, 1993, s. 34)

Yaver Paşa'nın komutanı olduğu Kırcaali Müfrezesinin mevcudu Aram Andonyan'ın "Balkan Savaşı" adlı eserine göre yaklaşık 16.000 'dir. Bunun 13.000'lik kısmı Kırcaali'de geriye kalan 3000'lik kısmı ise Paşmaklı'da yer almaktaydı. (Andonyan, 2002,s.493) Türk Silahlı Kuvvetlerince hazırlanmış olan "Edime Kalesi Etrafindaki Muharebeler" adlı kitapta Kurcaali Müfrezesinin mevcudu 18 Ekim 1912'de 21.155 olarak geçmektedir. (Genelkurmay, 1993, s.37)

Bir redif, bir müstahfiz tümeni ile 36.Piyade Alayı ve bağlı birliklerden oluşan Kırcaali Müfrezesi’nin savaşta üstleneceği görev şu ş̧ekildeydi:

Osmanlı Devletinin Doğu ve batı orduları arasındaki irtibatı sağlamak için İstanbul- Selanik demiryolu hattını muhafaza etmeleri gerekiyordu. Bu nedenle savaş başlar başlamaz vakit kaybetmeden şiddetle ve baskın şeklinde, Hasköy ve Tırnova-Seymen hattı üzerinde hareket ederek demiryoluna zarar verip düşmanı kendi üstüne çekerek ve yenilgi almadan bu işi tamamlamak zorundaydı. Kurcaali Müfrezesi'nin bu görevi gerçekleş̧irmek amacıyla kuvvetlerinin çoğunluğu Kırcaali'de bulunacak bir kısmı da Paşmaklı Bölgesinde bulundurulacak ve taarruz harekâtına ilk firsatta başlayacaktı. (Genelkurmay, 1993, s.46) Görüldügü̈ üzere, Kırcaali Müfrezesi'nin ana görevi Doğu ve Batı ordulanı arasındaki irtibatı sağlamak amacıyla İstanbul-Selanik demiryolu hattını korumaktı. Bu müfrezenin görevi aslında oldukça zordu. Eğer iki ordu arasındaki irtibat kesilirse Osmanlı ordularının yenilmesi muhtemeldi. Bu yüzden Kırcaali Müfrezesinin hiçbir hata yapmaması gerekiyordu.

Osmanlı ordusunun seferberliği çok zor şartlar altında gerçekleşti. Bu durumdan Kırcaali müfrezesi de etkilendi. Savaşın aniden patlak vereceğini düşünmeyen Osmanlı Devleti birçok askerini terhis etti. Savaş bir anda patlak verince terhis edilen askerlerin yerinin doldurulması için yoğun bir çaba sarf edildi. Fakat bu iş kolay olmadığ için mecburen birlikler rastgele askerlerle dolduruldu. (Murat, 1933, s.24)

Kırcaali mıntkasında yer alan 36.Nizamiye piyade alayı seferberliğini yaklaşık yedi gün içerisinde

\footnotetext{
${ }^{5}$ Balkan Savaşına Şark Ordusu Kurcaali Redif Tümeni Komutanı olarak katılııstır. 22 Kasım 1912'de Kurcaali Müfrezesinde yeniden teşkilatlanma yapılmış ve iki mürettep tümen haline getirilmiştir. Bu yeni teşkilatlanma da Albay Rasim Bey'in tayini yapılmış ve 1 nci Mürettep Tümen komutanlı̆ına atanmıştrr. (Genelkurmay, 2004, s.457)

${ }^{6}$ Albay Yusuf 5 Ekim 1912'de Şark Ordusu Kırcaali Müfrezesi Kırcaali Redif Tümeni Krrcaali Redif Alayı komutanlı̆ına atanmıştrr. Üstlendiği bu görev ile Balkan Savaşlarına katılımıștr. (Genelkurmay, 2004, s.458)

${ }^{7}$ Hüseyin Hüsnü Şark Ordusu Krrcaali Müfrezesi Kircaali Redif Tümeni 36 ncı Alay komutanı olarak görev yapmıştr. ( Genelkurmay, 2004, s.455)
} 
tamamladı. Kurcaali'deki diğer redif ve müstahfiz birlikleri seferberliği için silâhaltına alınacak kişilerin toplanmasında bir sorun yaşanmamış̦ır. Fakat birlikler istenilen mevcutlara ulaşamadan yola çıkmak zorunda kaldılar. Kırcaali müfrezesinin karargâhı ve bağhı olan kıtaları tam olarak şekillendirilemedi. Müstahfiz taburlarına askerlik çağına gelmemiş gençler ve ihtiyarlar alındı. Bu kişilerin çoğu silah kullanmasını bilmiyordu. Komuta kademesinde subay eksiği fazlayd. Mevcut olan komutanlar emir ve kumanda zincirinin ne olduğunu dahi bilmiyorlard. Aynca mevcut komutanların hiçbir seferberlik tecrübeleri de yoktu. Bu komutanların herhangi bir savaşı idare etme kabiliyetleri de yoktu. Bu yüzden Kurcaali müfrezesi İstanbul'dan ümera ve subay talebinde bulundu. İstanbul'dan gönderilen subaylar uzun süre askeri mektep ve müesseselerinde görev aldıkları için adeta sivilleşmişlerdi. Bu taburların elbise ve teçhizatları da yoktu. (Murat, 1933, s.24-25)

Tıbbi açıdan müfrezeye baktığımızda birçok konuda eksiğin olduğu görülmekteydi. Tüm Kırcaali Müfrezesinde 4 doktor ve 1 eczacı görev yapmaktaydı. Bununla birlikte tıbbi malzemelerin sayısı da oldukça azdı. Bu malzemelerin az olmasıın yanı sira kullanımı içinde bir arzu ve heves yoktu.

Kurcaali Müfrezesinin silah ve cephane durumuna bakacak olursak:

Nizamiye ve Redif birlikleri tekrar eden ateşli mavzer tüfeklerine sahipti. Müstahfizlar ise Martin tüfeklerini kullanıyorlardı. Bu tüfeklerin iğnelerinin dayanıksız olmaları ve yedek parçalarının bulunmaması önemli bir sorun teşkil ediyordu. Müfrezenin cephane durumu iyiydi. Cephanenin ikmali konusunda da zorluk yaşanmamıştı. (Murat, 1933, s.25)Kırcaali Müfrezesinin seferberliğine genel olarak baktığımızda, birçok açıdan sorunlu bir seferberlik süreci olduğu görülmektedir. Özellikle asker ihtiyacı konusunda önemli sorunların olduğu göze çarpmaktadır. Nitelikli askerlerin olmaması tüm Osmanlı ordusunda olduğu gibi Kırcaali Müfrezesinde de önemli bir sorundu. Cephane açısından Kurcaali Müfrezesinin herhangi bir sorunu olmasa da askerlerin tecrübesiz oluşu yapılacak muharebelerde mağlubiyetler alınmasına sebep olabilecek bir nitelikteydi.

\section{Mehmed Yaver Paşa'nın Bulgarlar İle Mücadelesi Ve Esir Düşmesii}

\subsection{Kircaali'den Fere'ye Kadar}

1912 yllının son aylarından birisi olan 20 Ekim'de Bulgar askerinin Osmanlı ordusunu mağlup ederek Kırcaali'ye girdiği bilinmektedir. Kırcaali'de bozguna uğrayan Yaver Paşa ordusu Gümülcine'ye doğru geri çekilmek zorunda kaldı. Buraya geri çekilmedeki amaç bozguna uğrayan etraftaki askerlerin Osmanlı ordusuna katılmasıydı. Bu bölgede yirmi bin Osmanlı askeri toplanmıştı. Toplanan bu kuvvetler Bulgar askerlerini ve özellikle Edirne kuşatma hattını korkutuyorlardı.

Bulgar ordusu toplanan bu önemli kuvveti takibe başladı. Güçlü bir kolordu Kurcaali’den Gümülcine'ye ve Dedeağaç'a doğru ilerlerken ikinci kuvvetli süvari kolu ise yavaş yavaş çekilmekte olan Yaver Paşa ordusunun Meriç Nehrinin sağ sahilinden geçmesini engellemekle görevlendirilmişti. Yaver Paşa’nın

\footnotetext{
${ }^{8}$ Makalemizin bu bölümünde dipnotta bahsetmiş olduğumuz eserden faydalanlacaktrr. Dipnotta belirtmiş olduğumuz eserin Osmanlı Türkçesinden Latin alfabesine transkripsiyonu ve sadeleştirilmesi yapılmıştrr. Bu eserde yazar bizzat şahit olduğu olayları tarih vererek anlatmıştrr. (Lesiçkof, 1913, s.4-13)
} 
Gelibolu' ya çekilmesinde başarılı olamamasının sebebi bu kuvvet oldu.

Üçüncü bir süvari kolu da Yaver Paşa kuvvetini sürekli olarak takip etmesi için görevlendirilmiş̧ti. Yaver Paşa kuvvetinin önüne sürekli olarak geçen bu kuvvet idi.14 Kasım günü dört beş bin kişiden meydana gelen Osmanlı ordusunun Gümülcine'ye çekileceği anlaşılması üzerine Bulgar kuvveti Bıdıklı'ya doğru çekildi. Bulgar süvarisi de düşmanın harekâtını takip edebilmek amacıyla Fere yanında kaldı.

18 Kasım'da Bulgarlar, Mestanlı'da bulunan Yaver Paşa ordusundan ayrı iki nizamiye taburu ve ileriki zamanda Kırcaali Pomak rediflerini oluşturacak olan birliklere karşı saldırıya geçtiler. Aynca bu birliklere ait olan seri atışı dağ bataryası ve iki mitralyöz üzerine de hücum yaptılar. Yaver Paşa’nın bu kuvveti bile mağlubiyete uğrayarak Gümülcine'ye doğru çekilmek zorunda kaldı.

$\mathrm{Bu}$ geri çekilme olayı adeta bir firar gibiydi. Çünkü dağlmış olan bu kuvvet pek çok savaş mühimmatını yol üzerlerine bırakarak kaçmışlardı. Bektaşlar köyü civarnnda ise 70 çadır her şeyiyle birlikte birakılmışt.

22 Kasım günü Bulgar kuvveti Gümülcine yakınlarında bir hücum gerçekleştirdi. Bunun üzerine Yaver Paşa kuvveti Fere istasyonuna kadar düzenli bir geri çekilme yapmak zorunda kaldı ve bu geri çekilmeyi gizli tutmak için de ordunun arkasında artçı bir kuvvet birakmıştı.

Bulgar kuvveti Yaver Paşa'nın ordusunu takip ederek Fere'ye yetişti. Meriç̧in sağ sahili üzerinden ilerlemekte olan Bulgar süvarisi ile münasebete başladı.

\subsection{Kurcaali'nin Zabtı}

22 Kasım 1912'de Bulgar askeri Kurcaali'yi ele geçirdi. Bu kasaba Arda Nehri'nin sol sahilinde yer almaktadır. Yaver Paşa'nın askeri Arda Nehri'nin sağ sahilinde yoktu. Yalnız başıbozuk Müslüman çeteleri dolaşıyordu. Ara sra bunlar Bulgar askeri üzerine hücum da gerçekleşiriyordu. Bulgar askeri 9 Aralık'ta Eskiler köyü civarından Ardayı geçti. Bulgar savaş erkânının amacı bütün Osmanlı kuvvetlerini güneye doğru sürmekti. Şiddetli yağmur yüzünden askerler pek güçlükle yürüyorlardı.

10 Aralık'ta Türkler geri çekilmeye, Bulgar ordusu ise artık ilerlemeye başlamıştı. 11 Aralık'ta Kışlaarası köyüne ulaştllar. Bu köyün yakının da bulunan Mestanlar kasabacığında Türklerin 4 parça seri atışı topu ile 3000 kişilik bir savaş kuvveti mevcuttu. Asıl muharebe Kurcaali de 14 Kasım'da başlamışst. Şiddetli geçen 14 Kasım muharebesinin ilk başlarında Türkler, Bulgar mevziilerine sızmaya çalışıllar. Fakat 17 Kasım'da Bulgarlara yardım kuvveti ulaşmıştı. Bundan sonra Bulgarlar ilerlemeye başladı ve Mestanlar kasabasına kadar dahil oldular. Yenilgiye uğrayan Türkler Gümülcine'ye doğru geri çekildiler.

\subsection{Gümülcine'nin Zabtı}

Gümülcine kasabası, Dedeağaç ile Selanik demiryolu hattı üzerinde bulunmakta ve Rodop sıradağlarının güneyinde yer almaktaydı 30.000 nüfusa sahipti. Halkın çoğunluğu Türklerden ve Rumlardan oluşuyordu. Bulgar sayısı pek azdı. Fakat kara Bulgar sayısı fazlaydı. 
Bulgar askeri 18 ve 19 Kasım 1912'de yol üzerinde hiçbir direnişle karşılaşmadan Gümülcine’ye doğru ilerliyordu. Mahmudlar köyü altında Türkler, tabyalar oluşturmuş ve güzel savunma mevkileri tutmuşlardı. Bulgar Makedonya Gönüllü livasına gece güzel mevziler almaları ve Türklere karşı saldırıya geçmeleri için emir verilmişti.

Makedonya Gönüllülerine yardımı Bulgar başıbozuk çeteleri yaptı. Bulgarlar, 20 Kasım’da Türkler ile önemli bir savaşa başladılar. Savaş Makedonya Gönülllüleri açısından çok zor şartlar altında geçti. Gece karanlığı çetelere Türkler yakınında bulunan mevzileri ele geçirmesinde yardım etmişti. Türkler yaylım ateşine başlamış ve Makedonya Gönüllülerine zarar vermişti. Türk toplarından mükemmel bir şekilde faydalanılmıştı.

Makedonya Gönüllüllerine yardım öğle vakti ulaştı. Türklerin geri çekilme hareketine engel olmak amacıyla Bulgar askeri düşmanını çevirme hareketine başladı. Fakat Türkler bu çevirme planını anladıkları için Şose yolu üzerinden Gümülcine'ye firar ettiler ve Fere civarında tutsak edildiler.

20 Kasım'da Kırcaali Bulgar ordusu bu kasabaya doğru ilerledi. Gümülcine'nin teslim olduğunu bilmedikleri için cebel toplanı ile kasaba üzerine top atışına başlamışlardı. Bununla birlikte süvariler de şehre doğru ilerliyordu. Gümülcine, 21 Kasım günü teslim oldu. Kasabanın ileri gelen Türk Müslüman eşrafi beyaz bayraklar ile Bulgar ordusunu karşılamış ve Rumların ileri gelen kişileri de şenlik havasında Bulgar ordusunu tebrik etmeye koşmuşlardı.

20 Kasım'daki muharebede Makedonya Gönüllülerinin 160 yaralısı ve 40 ölüsü vardı. Gönüllü̈ler arasında en faydalı olan bir Ermeni çetesi olmuştu. En çok bunlar zayiat vermişlerdi.

\subsection{Yaver Paşa'nın Esir Alınması}

26 Kasım 1912'de Yaver Paşa'yı takip eden Bulgar kuvveti düşmanıyla karşılaştı. Sonrasında her iki taraf top atışına başladılar. Bu top atışları öğleden sonra saat ikiye kadar devam etti.

Yaver Paşa, Bulgar kuvvetleri tarafindan açllan ateşten kuvvetlerinin zarar göreceğini düşündüğünden beyaz bayrak çekerek ve teslim müzakeresi yapmak için parlamenter göndermek zorunda kalmıştı. Türkler kabul edilemeyecek şartlar ileri sürdüğ̈̈nden Bulgar kumandanlanı buna ret cevabını vermişlerdi.

Top atışları ertesi gün yeniden başladı. Yaver Paşa'nın ordusu yenilmeye devam ediyordu. 28 Kasım günü Yaver Paşa ordusu yenilmekte olduğu için öğleden sonra tamamıla teslim oldu. Kırcaali ordusu kumandanı Mehmed Yaver Paşa, erkân-1 harp reisi Hayri Bey ordunun ileri gelenlerinden Fazıl Bey ve İmhoff Bey ve daha 265 subay ile 15000 asker savaş esiri olarak tutulmuştu. Bundan başka çok sayıda savaş mühimmatı 8 dağ topu, 2 mitralyöz, 1500 beygir, 400 vagon ve 8 makine ele geçirildi. Sadece Yaver Paşa ile erkân-1 harp reisi Hayri Bey, Fazıl ve İmhoff beyler Kırkkilise’ye götürüldüler. Diğer subaylar ise Bulgaristan'ın çeşitli şehir ve kasabalara gönderildiler.

Yaver Paşa'nın Kırkkilise'ye ulaşmasının ertesi günü otomobil ile Bulgar ordusunun merkezine sevk edildi. Burada harp harekâtı şubesi reisi Miralay Terezofa takdim edildi. Yaver Paşa, Bulgar ümerası ve subayları 
Bulgar Yazar İvan Lesiçkof'un Gözünden Balkan Harbinde Kırcaali Müfrezesi ve Mehmed Yaver Pașa'nın

Esareti/Sinan KOÇAK

tarafindan karşılandı. Bulgar subayları tarafindan gösterilen hürmet ve saygıya hayran kalan Paşa, teşekkürlerini iletmişti.

Sokaklar paşayı seyretmeye gelenler ile dolmuştu. Paşa'nın yaşlı olması bu duruma tesir eden etkenlerden biriydi. Yaver Paşa’nın kumandanı olduğu Kırcaali Müfrezesinin ileri gelen subaylarından birisi olan Fazıl Bey, Almanya'da eğitim görmüş ve bir Alman kızı ile evliydi. Almancayı iyi derecede konuşuyordu. Görüldüğü üzere Yaver Paşa neye uğradığını ve ne şekilde yenilip esir olduğunun henüz farkına varamamıştı. Çünkü Bulgar subayları bahsedilen muharebe durumunu hikâye ettikleri sırada Yaver Paşa göğüs gererek en son kendisinin teslim olduğunu söylemiş̧ir.

Yaver Paşa hemen Çar Ferdinand'ın huzuruna çıarılmış ve övgülerle şereflendirilmiştir. Ayrıca Çar Ferdinand Yaver Paşa ve arkadaşlarına kilıçlarıı taşımalarına da izin vermiş̧ir. Kendi istekleri üzerine Yaver Paşa ve arkadaşları Sofya'ya gönderilmiş̧ir.

Yaver Paşa ve erkanı teslim protokolünü imzalamıştı. Ancak Yaver Paşa'nın kontrolü altındaki ordu firar girişiminde bulundu. Fakat Bulgar kuvvetleri bu firarilere yetiştiler. ( $\mathrm{Bu}$ firar girişimi esnasında birkaç bin kişi Meriç’e atılmış veya boğulmuştur. Ayrıca Gelibolu'ya doğru firar edenlerde bulunmuştur. ) Sonuç olarak, Yaver Paşa'nın Kurcaali müfrezesi çok sayıda eşyalarıyla birlikte esir alındı.

Yaver Paşa kolunu esir eden Bulgar kuvveti, Keşan’ı da ele geçirmiş̧ti. Bundan sonra Bulgarlar büyük kuvvetlerini Mahmud Köy ve Pişman Köy etrafina yığdılar. Gelibolu'nun kuzey tarafindaki asker sevk noktasını ve Koru Dăg, Gobra ile Kuşka mevkilerini de ele geçirdiler.

Yaver Paşa ordusunun amacı aslında Filibe yanından Bulgaristan'a gitmekte olan Bulgar ordusunu Edirne'ye varmadan durdurmaktt. Fakat bu ordu Kurcaali'de ki ilk çarpışmada mağlubiyete uğramış ve işlevsiz kalmıştı.

\subsection{Dedeağaç Yanında Muharebe}

27 ve 28 Kasım 1912'de Dedeağaç civarındaki Bulgarların Gümülcine kolordusunun bir parçası olan Onuncu firka ile gerçekleşen savaşa birkaç tabur ve bir süvari livasından oluşan Makedonya ordusu katılmıştı.

Bu savaşı Türkler kesin olarak kaybetmiş̧ir. 650 kişiden oluşan 9 tabur savaş ganimetleriyle birlikte Bulgarlara teslim olmak zorunda kalmıştır.

Dedeağaç'ın ele geçirilmesiyle birlikte Edirne kuşatma kitası her türlü yardımdan mahrum kaldı. Bulgarlar Selanik, Siroz, Dedeağaç, Dimetoka ve Çatalca'yı ele geçirdikten sonra kendi ordularının ihtiyaçlarını fazlasıyla karşlamaya başladı ve bu durum pek kolay bir şekilde gerçekleşti. Askeri nakliyat işleri de bundan sonra olgunlaşmaya başladi. Dedeağaç ele geçirilene kadar Bulgarlar sadece ufak bir demiryolu hattından faydalanabilmiş̧i. Bulgar ordusunun ihtiyaçları Çatalca'dan Kırkkilise'ye manda arabalarıyla taşınıyordu. Daha önceden dört eski vagon ile bir bozuk makineden oluşan nakil vasitaları Bulgar ordusu için hesapsız vagonlara ve makinelere bağlıydı. Bununla birlikte bu hatlar müttefiklerin Çatalca'ya doğı yapacakları yardımlarını kolaylaşturması için yeterliydi. 


\subsection{Yaver Paşa Ordusu Ne Yapacakmış?}

İstanbul'dan gelen telgraftan anlaşlıyor ki Dedeağaç ile Dimetoka arasında Bulgarlar tarafindan esir edilmiş olan Türk askerinin sayısı 12.000 kişiden fazlaymış. Bu askerler Gelibolu için ayrlmış ve orada meşhur Şevket Turgud Paşa'nın kumandasında 60-70 bin kişilik bir ordu hazırlamak üzereymiş. Sonradan Yaver Paşa ordusu Şevket Turgud'un bu tertip olunmuş kuvvetine katılacak ve oradan Çatalca da yer alan Bulgar kuvvetleri üzerine gelecekmiş. Bunun üzerine bahsedilen ordusuyla beraber Yaver Paşa'nın esir düşmesi tüm Türk planını neticesiz bırakmış ve Şevket Turgud Paşa'nın Çatalca'ya dönmesine sebep olmuştur.

Buna dayanarak Çatalca yanındaki Bulgar askerine karşı ve özellikle boğazların kuzey tarafindaki cepheyi savunmak amacıyla Türkler planlarnı değiştirmiş ve bu değişikliğe Bulgarların askeri sevk düzeni ve hızı sebep olmuştur.

\section{Sonuç}

Kaynaklar incelendiğinde Balkan Savaşlarında birden fazla Yaver Paşa'nın adı geçtiği görülmektedir. Bunlardan ilki Ömer Yaver Paşa'dır. Ömer Yaver Paşa, Balkan Harbinde Doğu ordusuna bağh oluşturulan Birinci Nizamiye kolordusunun komutanıdır. Asıl konumuzda bahsettiğimiz Mehmed Yaver Paşa ise Doğu ordusuna bağı Kırcaali Müfrezesinin komutanıdır. Birçok kaynakta Mehmed Yaver Paşa'nın adı Kırcaali müfrezesi komutanı olarak geçmektedir. Ayrıca Hikmet Bayur'un "Türk İnkılabı Tarihi”" eserinde Kırcaali Müfrezesi komutanı olarak bir de Ali Yaver Paşa ismi geçmektedir. Hikmet Bayur'un böyle değerli bir eserinde bu şekilde geçmesi bizi iki sonuca varmamıza sebep olmuştur. Birincisi, Ali Yaver Paşa isminin yanlış olarak tespit edildiğidir. İkincisi ise Mehmed Ali Yaver Paşa olabilme ihtimalidir. Ancak kaynakların çoğunluğu incelendiğinde Kırcaali müfrezesinin komutanının Tuğgeneral Mehmed Yaver Paşa olduğu sonucuna varılmıştır. Özellikle bu sonuca varlmasında Genelkurmay'ın askeri arşiv belgelerine dayalı olarak hazıladığı "Balkan Savaşı'na Katılan Komutanların Yaşam Öyküleri’' adlı eserin önemli bir yeri vardır.

Kırcaali Müfrezesinin komutanı olan Tuğgeneral Mehmed Yaver Paşa, Balkan Harbinde esir düşen komutanlardan biridir. Kendi kaynaklarımız incelediğimizde Mehmed Yaver Paşa'nın üzerine düşen görevini hakkıyla yapamadığı ve bu yüzden esir düsşüğü bilinmektedir. Yani tüm suç Mehmed Yaver Paşa'nın üstüne kalmıştrr. Fakat bu hükmü vermek aslında işin kolayına kaçmaktır. Çünkü Kırcaali Müfrezesinin en başta seferberliği düzgün bir şekilde gerçekleştirilemediği bilinmektedir. Bununla birlikte Kurcaali Müfrezesinin subayları ve askerlerinin tecrübesiz oluşları bu müfrezenin üzerine düşen görevi yerine getirememelerinde etkili olmuştur. Mehmed Yaver Paşa, mağlup olmuş bir komutan olabilir ancak tüm suç Yaver Paşa'nın değildir. Ordunun komutasıyla ilgili yaptığı hatalar Yaver Paşa'ya aittir. Fakat elindeki imkânların kısttlı olması ve bu yüzden başarısız olması hususu da göz önünde bulundurulmalıdır.

İvan Lesiçkof'un "Balkan Muharebatı Hatıratından" adlı eserine baktı̆ıımızda Mehmed Yaver Paşa'dan övgülerle söz edilmiştir. Böyle söz edilmesinde Yaver Paşa ve müfrezesini esir ettikleri için duyulan sevinç etkili olmuş olabilir. Sonuçta sadece askerler esir alınmamış bunun yanında ordunun teçhizatı da 
Bulgarların eline geçmiştir. Savaş ortamında ordular için teçhizat önemli olduğu için Bulgarlar birçok ihtiyacını Kırcaali Müfrezesinin teçhizatlarıyla karşılamışlardır.

Lesiçkof'un bu eserini incelediğimizde Mehmed Yaver Paşa'nın teslim olmamak için ilk başlarda yoğun çaba sarf ettiği görülmektedir. Birçok kez ordusunu geri çekip daha sonra tekrardan taarruza geçmek için planlar yapttğı da Lesiçkof'un eserinde göze çarpmaktadır. Yaver Paşa tüm çareler tükendikten sonra ordusunun daha çok zarar görmesini engellemek amacıyla Bulgarlara teslim olmayı kabul etmiştir. Burada önemli olan husus şudur: Hasan Tahsin Paşa'nın tek bir kurşun atmadan Selanik’i teslim etmesiyle Mehmed Yaver Paşa'nın Bulgarlara teslim olması aynı şeyler değildir. Sonuç olarak, Mehmed Yaver Paşa başarılı olamasa da bir süre Bulgarlar ile mücadele etmiş ve sonucunda teslim olmak zorunda kalmıştr. 


\section{Kaynakça}

[1] Acaroğlu, M.Türker(1988), Bulgaristan'da Türkçe Yer Adları Kılavuzu, Sevinç Matbaası, Ankara.

[2] Akın, İlhan F(2017), Siyasi Tarih 1870-1914, Beta, İstanbul.

[3] Andonyan, Aram(2002), Balkan Savaşı, 2.Baskı, Aras Yayıncılı, İstanbul.

[4] Armaoğlu, Fahir(1999), 19. Yüzynl Siyasi Tarih( 1789-1914 ), 2.Bask1, Türk Tarih Kurumu, Ankara.

[5] Bayur, Y. Hikmet(1943), Türk İnkilabı Tarihi, Cilt 2, Kısım 1,Türk Tarih Kurumu, Ankara.

[6] Bayur, Y.Hikmet( 1943 ), Türk Inkilabı Tarihi, Cilt 2, Kısım 2,Türk Tarih Kurumu, Ankara.

[7] Bodur, Harun(2005), Kronolojik 20. Yüzyll Siyasi Tarihi,Çağlar Yayınları, Ankara.

[8] Çalık, Mustafa(2015), Bir Asır Sonra Balkan Savaşları,3.Baskı, Cedit Neşriyat, Ankara.

[9] Doğruöz, V.Türkan(2016), "Bir Bulgar Yazarın Gözünden Balkan Savaşları : Ivan Lesiçkofun "Balkan Muharebatı Hatıratından" Adlı Eseri”. Uluslararası Balkan Tarihi ve Kültürü Sempozyumu.Çanakkale.

[10]Genelkurmay Başkanlığı(1993), Türk Silahlı Kuvvetleri Tarihi, Osmanlı Devri, Balkan Harbi (19121913), Edirne Kalesi Etrafindaki Muharebeler, 2. Bask1, Cilt 2, Kısım 3, Genelkurmay Basımevi, Ankara.

[11]Genelkurmay Başkanlığı(2004), Balkan Savaşı’na Katılan Komutanların Yaşam Öyküleri (Alay ve Daha Üst Birlik Komutanları), Genelkurmay Basımevi, Ankara.

[12]Görgülü, İsmet(1993), On Ylllk Harbin Kadrosu 1912-1922 Balkan-Birinci Dünya ve İstiklal Harbi,TTK, Ankara.

[13]J.Erickson, Edward(2013), Büyük Hezimet Balkan Harpleri'nde Osmanlı Ordusu, Türkiye İş Bankası Kültür Yayınlan, İstanbul.

[14]Lesiçkof, İvan(1913), Balkan Muharebatı Hatıratından- Yaver Paşa’nın Esareti(Müt. M.Nuri), Cilt1, Cüz 1, Balkan Matbaasi, Filibe.

[15]Murat, Mehmet(1933),“1912-1913 Balkan Harbinde Kurcaali Kolordusunun Hareketleri”, Askeri Местиа, Say1 32, Aralik.( 24-25)

[16]Uçarol, Rıfat(2013), Siyasi Tarih(1789-2012), 9.Baskı, DER Yayınlan, İstanbul.

[17]Yalçın, Durmuş; Akbıyık,Yaşar vd.(2011), Türkiye Cumhuriyeti Tarihi I, 10.Baskı, Atatürk Araştırma Merkezi, Ankara.

[18]Y1ldırım, Bülent(2014), Bulgaristan'daki Ermeni Komitelerinin Osmanl Devleti Aleyhine Faaliyetleri( 1890-1918), TTK, Ankara. 
Bulgar Yazar İvan Lesiçkof'un Gözünden Balkan Harbinde Kırcaali Müfrezesi ve Mehmed Yaver Pașa'nın

Esareti/Sinan KOÇAK

\section{Ekler}

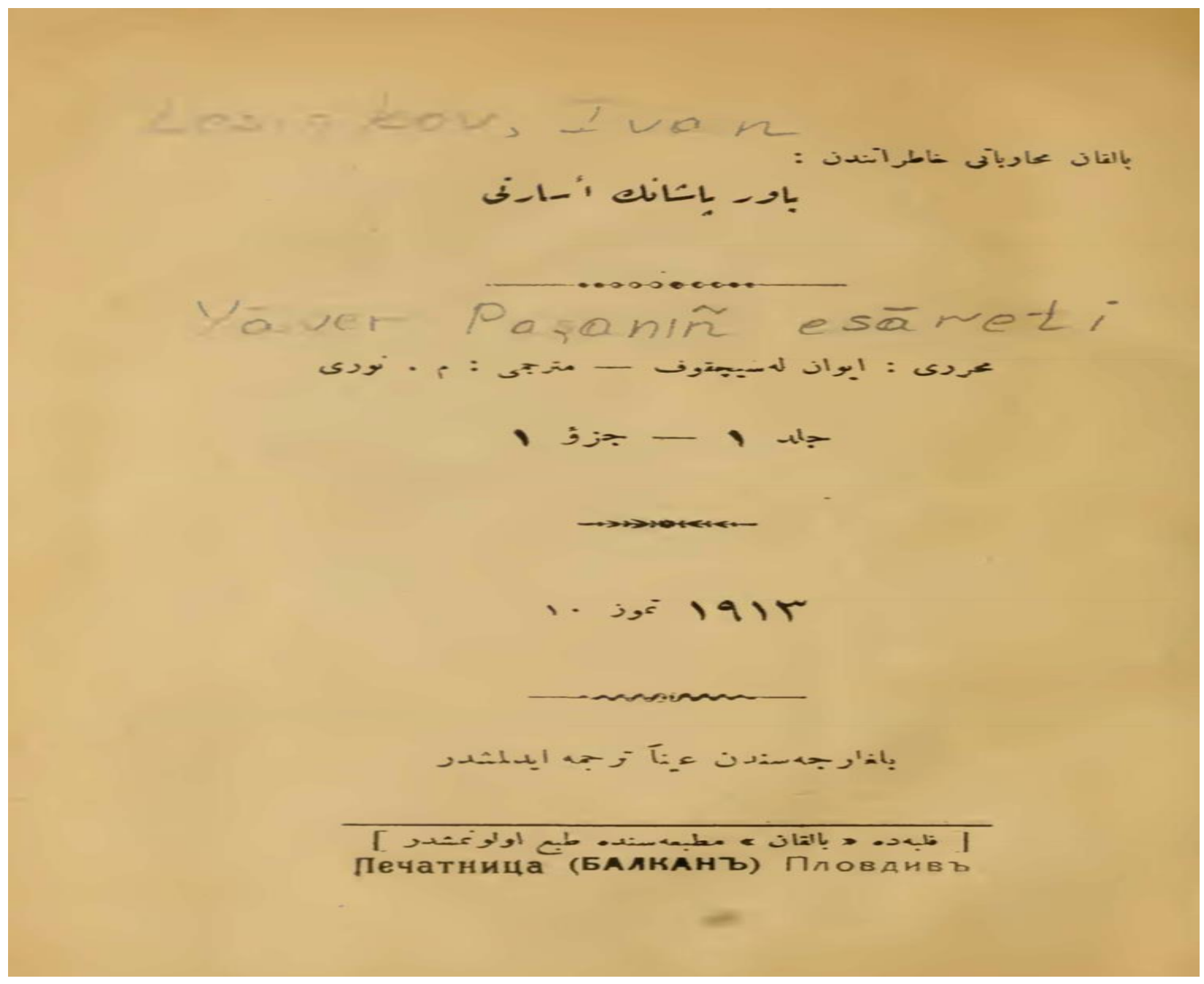

EK 1 : İvan Lesiçkof’un “Balkan Muharebatı Hatıratından” adlı eserinin ilk cüzünün kapağı 


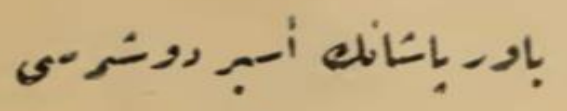

$-1-$

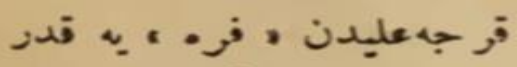

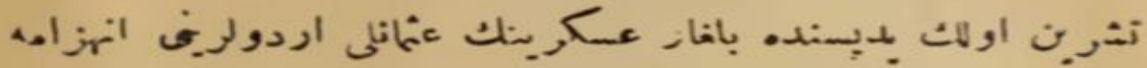

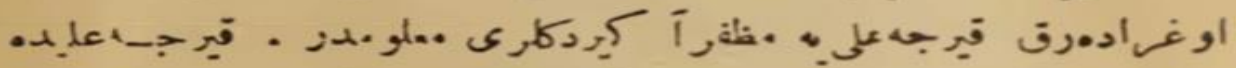

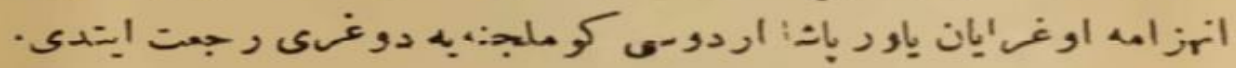

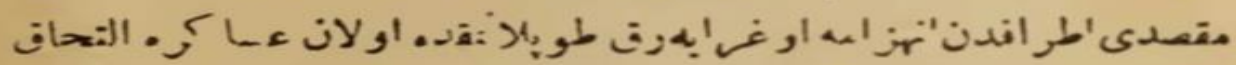

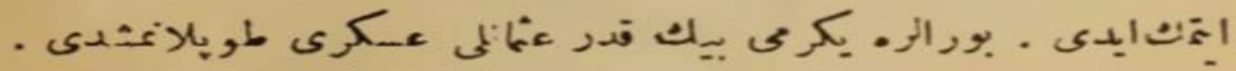

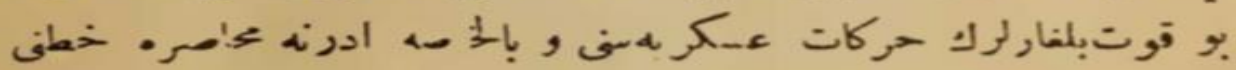

$$
\text { - }
$$

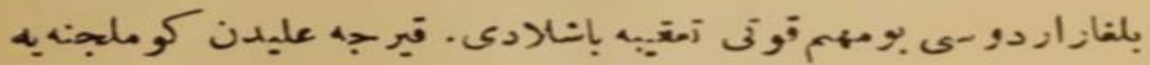

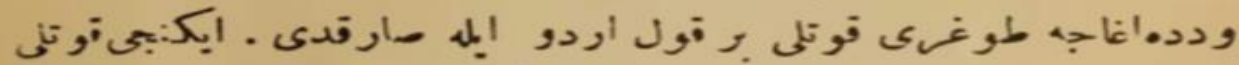

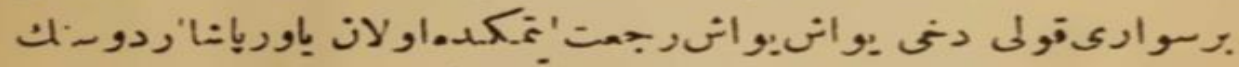

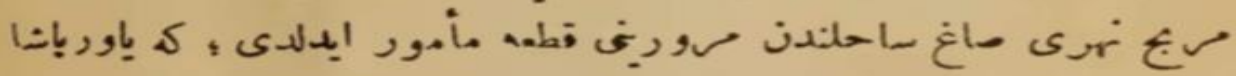

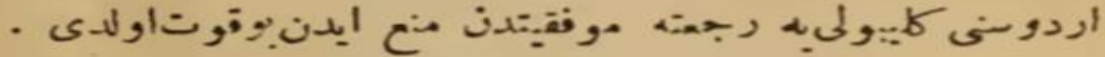

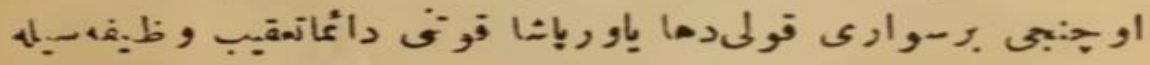

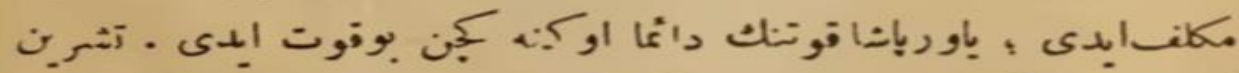

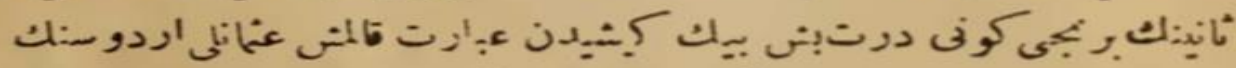

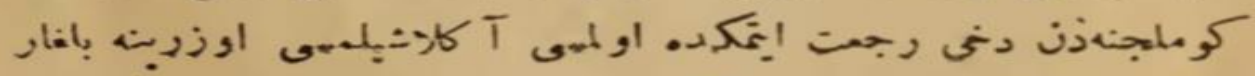

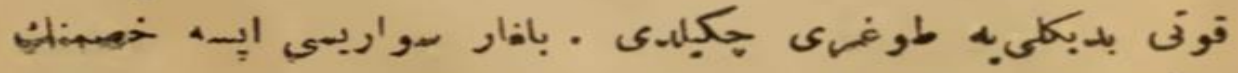

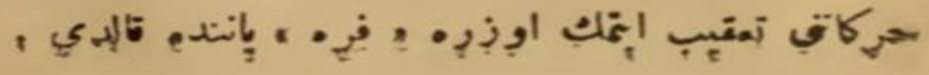

EK 2 : İvan Lesiçkof’un "Balkan Muharebatı Hatıratından" adlı eserinin ilk cüzü olan "Yaver Paşa'nın Esareti” adlı bölümden bir sayfa. 
Bulgar Yazar İvan Lesiçkof'un Gözünden Balkan Harbinde Kırcaali Müfrezesi ve Mehmed Yaver Pașa'nın Esareti/Sinan KOÇAK

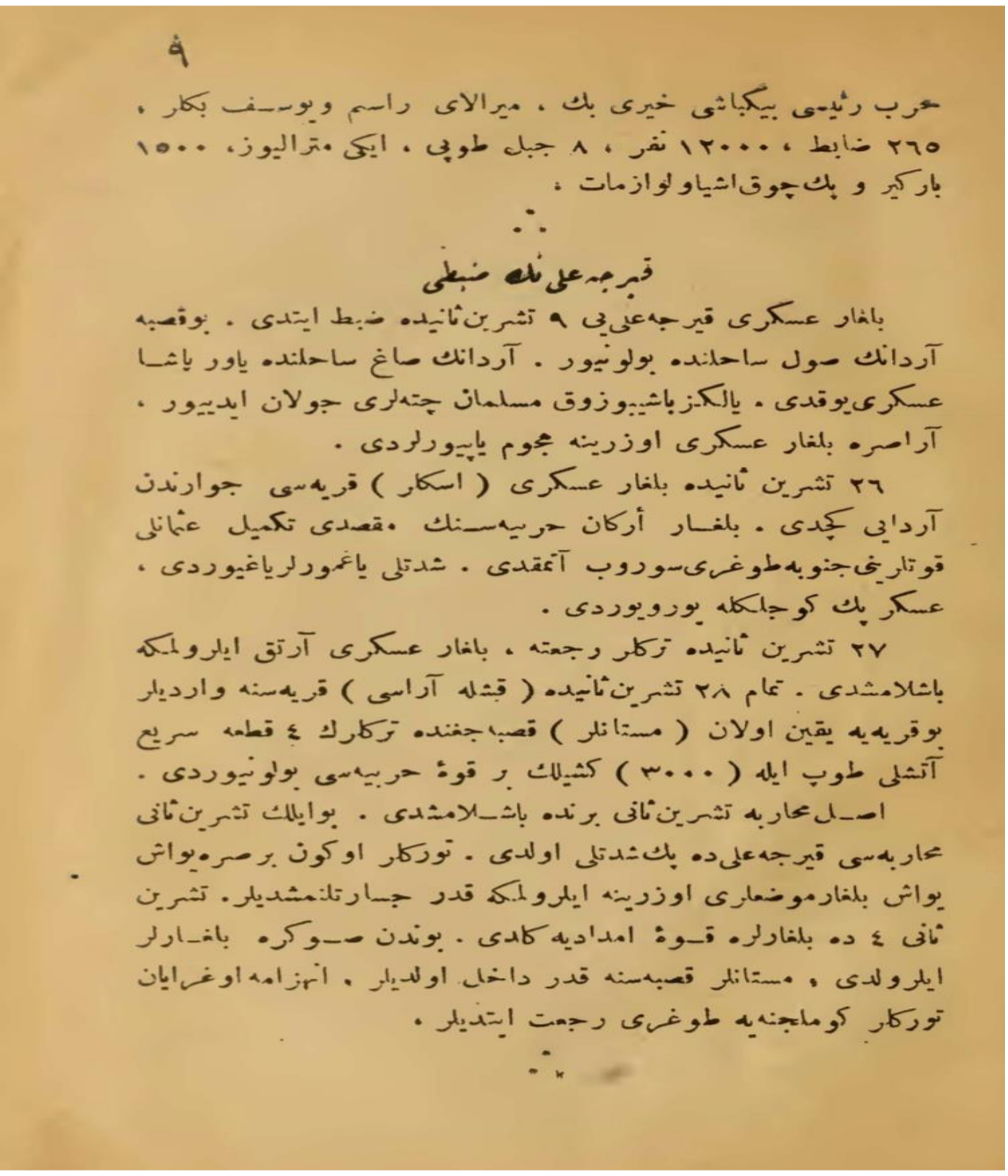

EK 3 : İvan Lesiçkof’un "Balkan Muharebatı Hatıratından” adlı eserinin ilk cüzü olan "Yaver Paşa'nın Esareti” adlı bölümden bir sayfa. 
ISSN: 2667-4432

Journal of Universal History Studies (JUHIS)・ 2(1) • June・2019 • pp. 154-172

11

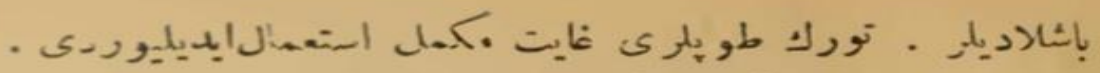

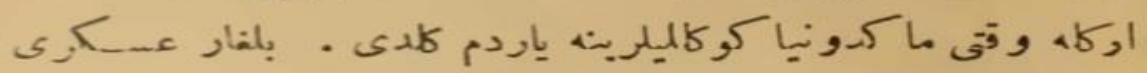

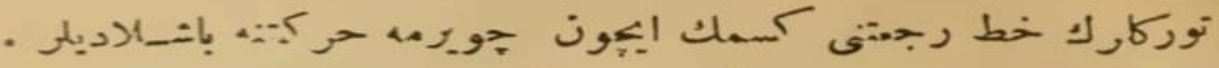

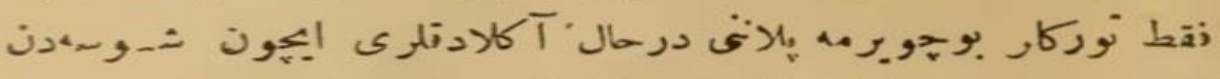

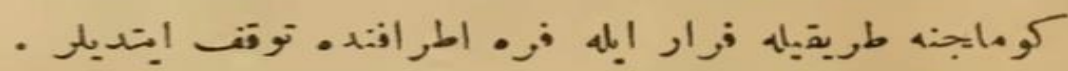

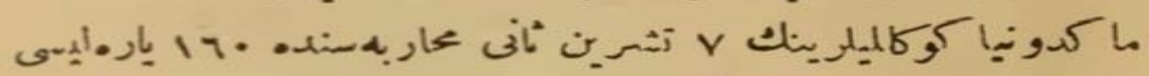

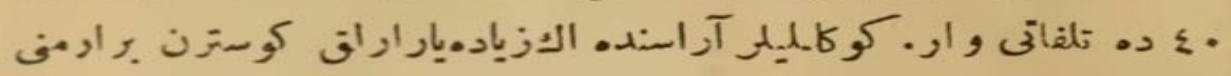

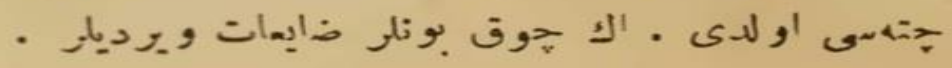

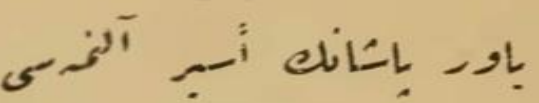

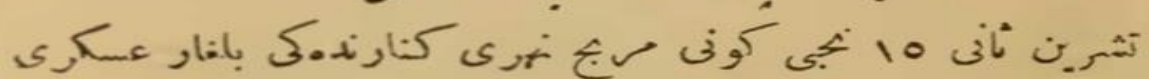

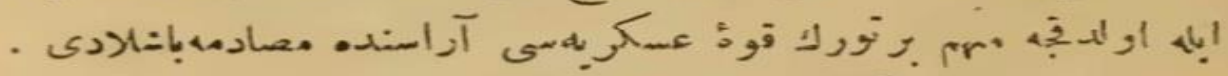

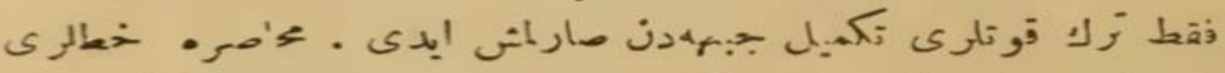

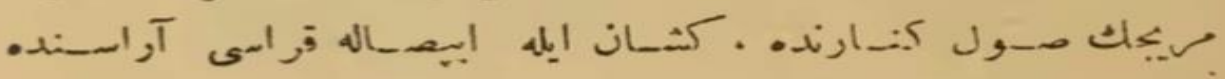

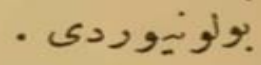

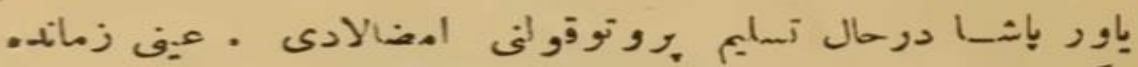

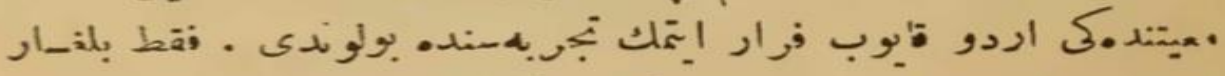

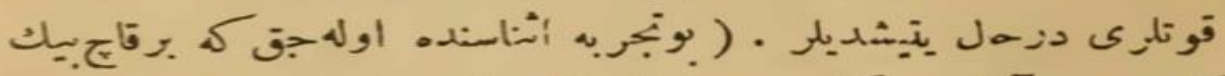

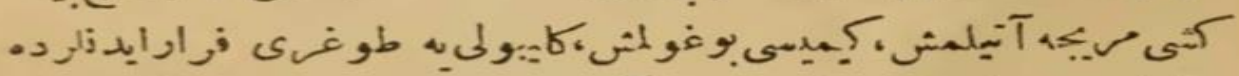

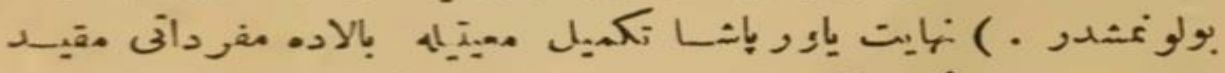

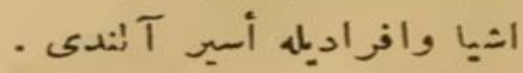

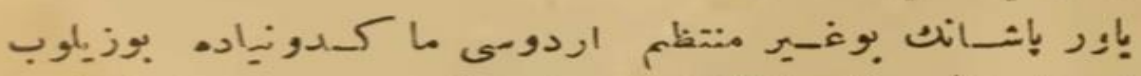

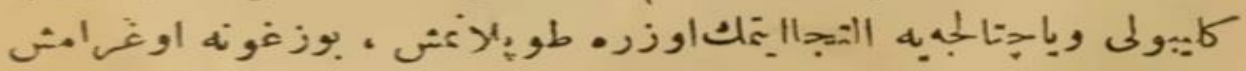

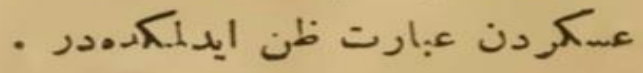

EK 4: İvan Lesiçkof'un "Balkan Muharebatı Hatıratından" adlı eserinin ilk cüzü olan "Yaver Paşa'nın Esareti” adlı bölümden bir sayfa. 